\title{
Problems and Countermeasures Research for Talents Training of Vocational Construction Engineering Technology Major
}

\author{
Xin $\mathrm{Liu}^{1 \mathrm{a}}$, Changyou $\mathrm{Li}^{1 \mathrm{~b}}$ \\ ${ }^{1}$ Liao Ning Urban Construction Technical College, 110122, China \\ a30154207@qq.com, b52819119@qq.com
}

\begin{abstract}
Keywords: Higher Vocational Education. Construction Engineering Technology Major. Talents Training. Problems and Countermeasures.

Abstract. In today's large-scale development of vocational education, vocational education has changed from level education to type education, vocational education training in the national economy shoulders the important task of high- skilled talents. Take the current situation of national vocational construction engineering technology major for example; it has gained plenty achievements in the professional construction and teaching reform, but there are also many deficiencies. In this paper, take Construction Engineering Technology Major in Liaoning Urban Construction Technical College for example, summarize the problems in the aspects of talents training of vocational construction engineering technology and propose feasible solutions.
\end{abstract}

\section{Introduction}

Vocational education, as a type of development of higher education, shoulders the mission of training the needed high-skilled talents in the first line for production, construction, service and management, and plays an irreplaceable role in the process of speeding up socialist modernization. As a recruit in the vocational education, our college, Liaoning Urban Construction Technical College, becomes full-time higher vocational schools with the approve of the People's Government of Liaoning Province in March, 2010. For three years of vocational education, our college has successfully passed talents training assessment and now we are struggling for provincial demonstration vocational college.

Construction Engineering Technology Major, as the first batch vocational major of our college, now has 845 students in the school, it is the largest major of our college, and it is also our college's focuses building major. Experience of Secondary vocational school for 28 years and higher vocational school for three years tell us that essence of vocational education is still career education, it needs to meet the economic society, particularly the need of high-skilled talents in the regional economy. Take the current situation of national vocational construction engineering technology major for example, it has gained plenty achievements in the professional construction and teaching reform, and it also summarize a lot of valuable experience, but there are also many deficiencies. This paper combined with the practical development experience of Liaoning Urban Construction Technical College generalizes, summarizes and analyzes the common problems of professional talents training, and it provides brainstorming for professional talents training in higher vocational school construction engineering technology major.

\section{High employment rate, ignoring the quality of talents training}

Problems. By the end of 2012, there are about 1300 National Independent higher Vocational Colleges, it has accounted for half of higher education, there are more than 300 million graduates each year, one third of the higher vocational college sets up construction engineering technology major, the main reason is that this major can provide good career and Rigid demand is large. Real estate, as an important industry at all levels of governments in China, is directly related to economic 
index. Although the nation has adopted a number of policies to control housing prices, but the huge rigid demand and national urbanization necessarily need a lot of talents engaged in engineering construction, this is the main reason that each college sets up construction engineering technology major. In this context, lack of professional teaching conditions, the declined quality of professional talents training is often neglected; it doesn't reach the basic requirements for engaging in positions for site construction technology.

Countermeasure. In addition to concern the employment rate, we should pay more attention to major counterpart's rate and business satisfaction. We combine industry position technical standard with professional teaching details. This year, the graduates from construction engineering technology major in our college counterpart's rate reached 86.5 percent, business satisfaction reached 91.8 percent. In the aspects of the professional teaching, this major has combined the standard of national construction site technical positions with teaching details, it makes students to work while they graduate, when they work, they can be quickly used. With the development of the construction industry, the ability of professional technical talents is a fundamental of the industry development, and is also fundamental driving force of professional development.

\section{The practical teaching conditions are restricted by lack of funds}

Problems. Lack of funds is common problems in every higher vocational college. Although we all belong to the higher education, there are still large gaps in the average allocation and tuition fees from undergraduate universities. In this limit, every higher vocational college has to enlarge enrolment to catch up with its fast development, while the practical teaching equipments and site conditions of different majors have been far behind its expansion; some majors have existed in name only. Take construction engineering technique major as an example, it need the real situation and the construction process to simulate the site. Now we are facing so many problems such as the complicated and diversified causes of the structure, the investment, and the lands. Nowadays most higher vocational colleges have established internal training bases under the limited financial conditions, but they are far behind the size of their own majors and practical needs.

Countermeasures. We must declare educational construction projects of municipal, provincial and national level to widen the channel of funds. Now our major has two provincial and national projects and we've got 5,500,000 $\$$ from the World Bank and 4,400,000 RMB from the central treasury. These funds have played an important role in the major's development. Meanwhile, we also established the training bases and started training programs together with enterprises to improve bases utilization and to get a methodical approach to work.

\section{Inaccurate specialty orientation influences the development trend of every major}

Problems. According to the 12nd document of the Ministry of Education in 2011 "Some suggestions on the vocational education reform and innovation to lead the scientific development of vocational education”, higher vocational education has double nature of higher education and vocational education. Its main task is to cultivate high-quality, skilled talent applied in production, establishment, management and service. It was brought forward on the latest educational reforms conference that higher vocational education should train high level professionals. The development of higher vocational education needs the change of training target. For example, the jobs of construction engineering technique major are complex, dangerous, and the working conditions are poor, therefore, professional skills can't achieve rapid technological developments. Simple training of professional knowledge and positon training can't meet the demand of industry development, while higher vocational colleges still take pratical working, measuring process and other practical systems as major courses. In this way, we will overlook that deep foundation and overall quality are keys for student's further development and we will limit the sustainable development of this major.

Countermeasures: After the localization of talent training, we must neglect theories and emphasize practices to broaden our knowledge; we must carry out educational reforms different from 
undergraduate universities and secondary vocational schools. Our major has already speculated the reform of education on the basic of public and professional areas of learning according to vocational positions demand. We have not only enhanced the technical ability, but also broadened students' knowledge as well. Therefore, we can provide the foundation for their future growth. In the meantime, we have offered some new courses for students such as: College Career Planning, Graduate Vocational Counsel and etc. to develop students' comprehensive quality.

\section{The reform of technical teaching was not thorough enough, which has reduce the students' enthusiasm to participate in}

Problems. The reform of technical teaching is a key way for the develop of the education in vocational school, we need to break the traditional teaching method in personnel training mode, course system, course content, teaching methods and examination methods, which is a matter of the first importance. At present most of the school building engineering while recognizing the importance of reform, but the lack of effective means of implementation. Talent cultivation mode of undergraduate curriculum system of applied mode, without breaking the old tradition, reform project of the formalization, evaluation method is too old, it is an urgent task. Professional architectural engineering technology in most school compared to the National Demonstration School of the gap significantly in terms of teaching idea of higher vocational education, teaching reform is not up to the national requirements for the development of higher vocational professional, most professional just in order to fight the project consistent with the requirements of the declaration of materials such as text, really hard to implement.

Countermeasure. Talent cultivation mode is a professional top design, the professional talent training scheme in multiple rounds of revision process determines the mode of training talents training, school-enterprise cooperation, and combining with engineering practice of post. Practice of action-oriented world mainstream educational thought, the working process-oriented curriculum system and the content of education, vigorously promote the project of curriculum reform, the comprehensive situation analysis for not suitable for reform project courses, to make students participate in the teaching process. Set up doing, learning by doing teaching concept, thoroughly reform the traditional teaching mode to the school and classroom as the center, pertinence, flexibility and openness of the outstanding talent, and fully mobilize the enthusiasm of students.

\section{The post training of risk, which has hindered the students' professional skills training}

Problems. Architectural Engineering Technology Specialty Facing the jobs mainly is the construction of an engineering and technical personnel, requirements of practical skills outstanding, have hard-working dedication and strong sense of responsibility, this is all employers value most, and develop the practical skills required a lot of practical teaching as a guarantee. In practical terms, most of the schools of the professional training is difficult, the majority of the post practice and professional training together, the students did not receive system comprehensive job skills training directly to the production line is engaged in the related work, the enterprise undertakes the training task, can' $t$ achieve the graduation certificates. But the professional engaged in the work of risk of large, complex environment of the scene, a lot of work is concealed work (after the process, the former process unseen) can't reproduce, engineering quality problems once will cause great economic loss, engineering accident, died or injured, most enterprises do not receive not graduated students to the production line in the construction work is also reasonable.

Countermeasure. Students of professional skills train in the real work environment, but the actual project of time, space, types and risk limits the field practice teaching. In order to realize the professional post skill practice better, on the campus of the construction site to carry out simulation of real construction site construction workers, librarians, materials, quality inspector, safety officer, standard members post training, according to the post standard training students on campus. At the same time for some construction techniques and engineering accident complicated cases, repeated 
practice and virtual demonstration of the use of digital virtual technology, which solves the project on time and space constraints, but also to avoid the dangerous work, and solve the quality and safety of the accident can't be copied, used in recent years to very good results. At present, we are developing the digital virtual construction comprehensive training field, enrich teaching means.

\section{Student occupation skills limited due to enterprises low teaching enthusiasm}

Problem. College-enterprise cooperation is considered to be the main method of reform and development of higher vocational education. Compared with the developed countries' education, the main gap is that China's enterprises have little enthusiasm to participate in teaching. At present most construction engineering in china contact with enterprises actively and want to establish a long-term cooperation with them, especially hoping enterprises to contribute to teacher's qualities, college construction and school employment. But in fact, most enterprises have little enthusiasm to participate in teaching due to college's low professional technical research ability and little help providing for enterprise so as not to achieve a win-win situation, for another reason is that college could not provide relevant economic returns for enterprises when they participate in the teaching process. Particularly in the construction engineering, the insufficient number of technical staff for enterprises, the increasing enterprise survival pressure, frequent staff mobility that makes the first-line technical staff can't come out and college students can't come in, these are the true reality for college-enterprise cooperation in construction engineering.

Countermeasures. Use the advantage of industry, increase policy support and make enterprise initiative. Our school is in Liaoning Province Department of housing and Urban-Rural Construction subordinate institutions, strong industry background to make the professional has made some achievements in the school-enterprise cooperation. Director of the provincial building housing the office of the director is a member of the director of our cooperation committee, in our school 30 years anniversary, in the province of housing department under the advocacy of the province, more than 100 companies donated $3000000 \mathrm{RMB}$ for the school. At the same time, we use its own equipment, personnel and technology advantages, through the school of engineering quality inspection center, Center for real estate research center study on energy saving and provide technical support to enterprises, and enterprises make more closely linked, cooperation a win-win. Shenyang Hanna Concrete Co. Ltd. is a Korean - owned enterprises, the company for 6 consecutive years in the professional scholarships and grants, long-term cooperation and makes the students identified Hanna concrete brand, students in the development of enterprises and enterprise development has played a positive effect.

\section{Summary}

In recent years, the State Council established the system of occupation education work of the inter-ministerial joint meeting, it should be said that the management system and operation mechanism of the last big push. But the occupation education still exists under the planned economic system, the government intervention, thus affecting the overall occupation education and healthy development. Higher vocational education must return to education, especially the construction engineering technology will become more and more urgent. With the vigorous development of the construction industry and continuous improvement to improve, the demand for talent will also have higher requirements, we are taking advantage of development, overcome the hardships and dangers along the way, in order to usher in the healthy development of the professional tomorrow. 


\section{Subject research}

Project supported by the study on the construction shortage of talents' training mode of high-end skills and scheme, special subject of research bases in Liaoning, China (Grant No. JGZXY11036).

\section{References}

[1] Dayuan Jiang: New vocational education research [M].Beijing: Educational Science Publishing House, 2007.

[2] Xinping Pan: On the characteristic professional construction in higher vocational colleges [J]. Journal of Liaoning Higher Vocational, 2012(6).

[3] Lingyan Kong, Jianjun Liu: On the formation and development of higher vocational colleges' characteristics [J]. 2013(4). 